BULLETIN Bulletin hispanique

HISPANIQUE Université Michel de Montaigne Bordeaux

\title{
Historia de la Literatura Ilustrada Española del Siglo XIX
}

Santiago de Compostela-Santander: Publicaciones de la Universidad de Santiago de Compostela y Universidad de Cantabria, 2019

\section{Carlos Miguel-Pueyo}

\section{(2) OpenEdition}

\section{Journals}

Edición electrónica

URL: http://journals.openedition.org/bulletinhispanique/11912

DOI: 10.4000/bulletinhispanique. 11912

ISBN: 1775-3821

ISSN: $1775-3821$

Editor

Presses universitaires de Bordeaux

Edición impresa

Fecha de publicación: 20 diciembre 2020

Paginación: 770-774

ISBN: 979-10-300-0606-3

ISSN: 0007-4640

Referencia electrónica

Carlos Miguel-Pueyo, «Historia de la Literatura Ilustrada Española del Siglo XIX», Bulletin hispanique [En línea], 122-2 | 2020, Publicado el 14 diciembre 2020, consultado el 19 enero 2021. URL: http:// journals.openedition.org/bulletinhispanique/11912; DOI: https://doi.org/10.4000/bulletinhispanique. 11912

Este documento fue generado automáticamente el 19 enero 2021.

Tous droits réservés 


\section{Historia de la Literatura Ilustrada Española del Siglo XIX}

Santiago de Compostela-Santander: Publicaciones de la Universidad de Santiago de Compostela y Universidad de Cantabria, 2019

\section{Carlos Miguel-Pueyo}

\section{REFERENCIA}

Historia de la Literatura Ilustrada Española del Siglo XIX. Raquel GUTIÉRREZ SEBASTIÁN, José María FERRI COLL, Borja RODRÍGUEZ GUTIÉRREZ (eds.),- Santiago de CompostelaSantander: Publicaciones de la Universidad de Santiago de Compostela y Universidad de Cantabria, 2019, 573 p. ISSN 0569-9924

1 La presente colección de trabajos culmina la trayectoria de sus editores, como de los autores participantes, en torno al diálogo entre la imagen y el texto en toda la literatura de la centuria decimonónica en España. Sus editores, Raquel Gutiérrez, José María Ferri y Borja Rodríguez, ofrecen en este volumen una visión total del fenómeno de la literatura ilustrada, atendiendo a una rica lista de autores y obras.

2 El volumen viene prologado por una visión general de la mano de Leonardo Romero Tobar donde, dirigiendo la mirada hasta la literatura griega del periodo helenístico, pasando por la «écfrasis», Horacio, y otros experimentos sensoriales evocados por las diferentes Artes en el tiempo, evoca las circunstancias sociales que permitieron la convivencia totalizadora entre texto e imagen de la literatura ilustrada: el aumento de la alfabetización, el papel propagandístico del material impreso, la modernización de la imprenta, y la ambición de la empresa editorial, abonaron un rico panorama de literatura ilustrada. Fenómenos como el grabado xilográfico a testa, la litografía, la cromolitografía o el fotograbado, son algunos de los nuevos ropajes que adopta el texto literario. De entre todos los enfoques tomados por los autores de este rico volumen, tal vez sea la relación entre el autor literario y el artista gráfico el eje vertebrador de todas 
las aportaciones del mismo, lo cual muestra un diagnóstico preciso de las necesidades y circunstancias que originaron la literatura gráfica decimonónica española.

Este volumen se divide en secciones según el género literario que tratan: narrativa, costumbrismo, teatro, poesía, prensa, y otras formas literarias. La primera de ellas aglutina una significativa nómina de autores y obras que se dejaron seducir por las posibilidades de la ilustración: Enrique Gil y Carrasco, Mariano José de Larra, Juan Valera, José María de Pereda, Benito Pérez Galdós, Leopoldo Alas, Emilia Pardo Bazán, Armando Palacio Valdés, y Jacinto Octavio Picón, así como tres capítulos dedicados a la literatura fantástica, la ciencia ficción, y la novela histórica.

4 Monserrat Ribao analiza las veinte ilustraciones de la primera edición de El señor de Bembibre de Gil y Carrasco (1844), apuntando que existen dos niveles de lectura: de un lado, el literario, personal de Gil; de otro, el visual, más volcado en el aspecto estético. En cualquier caso, concluye la autora que el texto icónico funciona como reclamo para el lector romántico, y que silencia la individualidad estilística del autor.

5 Ángeles Ayala echa una mirada a El doncel de don Enrique el doliente, de Larra, en su edición de 1850 y 1852, con setenta y ocho grabados y treinta y ocho láminas litografiadas de Vicente Urrabieta. El encarte de las ilustraciones permite al lector seguir el texto literario de la mano de las bellas imágenes. Subraya la autora aspectos visuales como la luminosidad y el efecto de claroscuro de las mismas, que completan perfectamente el hilo narrativo.

6 Juan Molina se acerca a Juan Valera para indagar lo sentimental y lo costumbrista, destacando que, en el caso de Pepita Jiménez, en edición de 1888 de Nueva York, es el texto el encargado de proporcionar la evolución psicológica de los personajes, mientras que las imágenes captan ciertos elementos castizos en algunos personajes. Sin embargo, en Juanita la Larga, en su edición de 1899, sus casi noventa ilustraciones, lejos de reflejar rigurosamente la cronología del relato literario, se esfuerzan por aportar abundantes detalles como el paisaje urbano, las fiestas de los pueblos, $u$ objetos significativos de la trama, entre otros.

7 Raquel Gutiérrez atiende a las obras literarias ilustradas de José María de Pereda que se publicaron en vida, a saber: El sabor de la tierruca (1882), Al primer vuelo (1891), la reedición de Tipos trashumantes (1897), y los relatos «Las brujas» (1896), «Agosto. Bucólica montañesa» (1889), y «Para ser buen arriero» (1900). Del primer título, destaca la autora la colaboración entre el dibujante, Apel-les Mestres, y el grabador, C. Verdaguer, y que ofrece como resultado un momento en la forja de la imagen pictóricoliteraria de Cantabria. Al primer vuelo ofrecía dos volúmenes con viñetas e ilustraciones. Todas ellas refuerzan la imagen de los personajes pero no la recreación del ambiente. Tipos trashumantes fue editada en 1897 con ciento diecisiete dibujos de Mariano Pedrero, la mayoría de los cuales corresponden a motivos ornamentales, florales y marítimos. Los tres relatos mencionados son muestra del gusto que Pereda desarrolló por el elemento ilustrado de su obra, de forma que en el futuro comprobó asiduamente el estado de las ilustraciones que adornarían sus textos.

8 Ángeles Quesada revisa las obras ilustradas de Galdós, encabezadas por la afirmación del mismo autor de que la «difusión de las imágenes fomenta la costumbre de pensar». Incluso se refería a esta colaboración como «texto gráfico-léxico». Las obras de Galdós que aparecieron ilustradas fueron los Episodios Nacionales (1881-1885), así como numerosos relatos, entre cuyos títulos constan «Celín» (1889), «El pórtico de la gloria» (1896), «Dos de mayo de 1808. Dos de septiembre de 1870». En todos los casos, concluye 
la autora, la admiración galdosiana por la ilustración no le permitió siempre ejercer autoridad en la creación y disposición de las ilustraciones, aunque ello no condicionó el texto literario.

9 Revisa también Quesada la obra ilustrada de Clarín, consistente en La Regenta, Las dos cajas, y algunos relatos que aparecieron en las revistas Apuntes y Madrid Cósmico. La Regenta apareció editada en 1884 y 1885, en sendos volúmenes con ilustraciones de Juan Llimona y Francisco Gómez Soler. Son ilustraciones sencillas que se centran en la historia de amor del protagonista. Las ilustraciones a textos de Clarín en el Madrid Cómico son obra de Ramón Cilla, que crea imágenes para seis de los ocho relatos. En cuanto a la publicación Apuntes, Galdós publica en él tres relatos: «La fantasía de un delegado de hacienda» (1896), «En la droguería» (1896), y «El entierro de la sardina» (1897).

10 El caso de Emilia Pardo Bazán es un tanto único, pues presenta una extensa obra que cedió espacio a la ilustración, por varias razones, entre ellas, como afirma Ángeles Quesada, por su popularidad, así como por razones económicas, que llevaban a la escritora a publicar en numerosas revistas, y en la inmensa mayoría de los casos, la ilustración aparece en términos fieles al texto.

11 Armando Palacio Valdés es recordado por Raquel Gutiérrez, y la novela Marta y María (1883), ilustrada por Pellicer con setenta y siete ilustraciones, consistentes en retratos, escenas, y decoraciones, que reflejan fielmente la acción de la obra, denotando una preferencia por el amor puro, frente a una religiosidad mal entendida.

12 Jacinto Octavio Picón, periodista y pintor, autor de siete novelas y colecciones de cuentos, es traído a colación por Raquel Gutiérrez. Su novela La honrada, ilustrada por José Luis Pellicer y José Cuchy Arnau, ofrece bastante fidelidad entre formatos, y su elemento visual intenta reivindicar la situación de desamparo de la mujer ante un mal matrimonio.

13 Juan Molina Porras revisa brevemente la literatura fantástica ilustrada, que cuenta con escasas muestras. También se refiere a la ciencia ficción decimonónica, que contó con pocos títulos como los Cuentos de Fernández Bremón (1878), o Cuentos inverosímiles de Carlos Coello (1878), que combinan acertadamente las ideas de Verne y Darwin, cuya estela curiosa continuarán otros escritores del XX como Pardo Bazán o Unamuno. Finalmente, la novela histórica de fin de siglo es revisada por Borja Rodríguez, centrándose en La leyenda del rey Bermejo, publicada en 1890, como el último título de la Biblioteca Arte y Letras. El autor literario era Rodrigo Amador de los Ríos y Fernández de Villalta, con dibujos de Isidro Gil y Gavilondo, y es este caso un ejemplo perfecto de primacía del elemento visual sobre el literario, cuyo texto literario tiene la función, según Borja Rodríguez, de «dar un motivo narrativo a las imágenes».

14 El siguiente bloque de estudios se centra en el costumbrismo y atiende, primero, a las ilustraciones que acompañaban el Panorama matritense y las Escenas matritenses de Ramón de Mesonero Romanos, siguiendo con una visión de Larra como costumbrista evocador sin imágenes, continuando con una mirada a la primera edición de las Escenas andaluzas de Serafín Estébanez Calderón, y terminando con el análisis de Los españoles pintados por sí mismos.

15 Enrique Rubio Cremades analiza Panorama matritense de Mesonero Romanos, serie de cuadros costumbristas que inicia en 1833 en la revista Cartas españolas, y que no ofrece ninguna rentabilidad. Tras esta experiencia, junto con sus viajes por Europa, como 
apunta Rubio Cremades, Mesonero encara su proyecto del Semanario Pintoresco Español con la clara idea de que las nuevas tecnologías deben enriquecer esta publicación. De esta forma, el grabado viene de molde para dar cuerpo al costumbrismo. El Panorama contará en sus ediciones con grabados de Gerardo Pérez Villaamil, Francisco Ortego y Vereda, Ildefonso Cibera, Joaquín Sierra Ponzano o Tomás Carlos Capuz, y Gaspar y Roig, siendo esta última edición la más cuidada. Durante las diferentes ediciones de Panorama matritense, se van produciendo interesantes circunstancias, como el hecho de que a veces se copian imágenes con alguna variación, como la postura de un personaje, o la omisión del autor del grabado.

Un breve capítulo de mano de Borja Rodríguez alude al Larra sin imágenes, hecho que deriva de la propia biografía del escritor, pues murió antes de que se desarrollara la literatura ilustrada. Por consiguiente, cuando en el futuro se crean ediciones ilustradas de Fígaro, no era ya posible "pintar» costumbres ya inexistentes. Como resultado, los ilustradores optaron muy a menudo por ofrecer imágenes del propio Larra, en lugar de recrear escenas, imágenes que definieron a Larra a final de siglo.

Un axioma asumido por los estudiosos, ése que admite el trío costumbrista de Larra, Mesonero Romanos y Estébanez Calderón, sirve a Borja Rodríguez para analizar la primera edición de Escenas andaluzas de Estébanez Calderón de 1847, ilustrado por Francisco Lameyer. De los ciento veinticinco dibujos que enriquecen esta edición, el ilustrador da clara preferencia al retrato individual o en pareja, sesenta y dos del total. Esta representación individual pretende reflejar la descripción detallada y pormenorizada de los personajes por parte del escritor.

Finaliza esta sección costumbrista una referencia a Los españoles pintados por sí mismos de Mesonero Romanos de 1843, por parte de Borja Rodríguez. Según él, la obra con ilustraciones de Ortega, pretende rescatar del olvido unos tipos, cuya españolidad el paso del tiempo está ya difuminando, por medio de la literatura y la pintura, y que responde, como ha afirmado Leonardo Romero, al talante práctico de aceptación, y de observación, de los cambios sociales de ese tiempo. Como afirma Borja Rodríguez, aunque el prólogo a la edición, a cargo de Rodríguez Rubí, adelanta un costumbrismo nostálgico que mira un casticismo que se está yendo, los ilustradores giran su mirada a la realidad contemporánea que traerá el realismo.

19 Sigue después una sección dedicada a la edición teatral con ilustraciones, a cargo de Montserrat Ribao. Dentro de la escasez de obras teatrales ilustradas, son tres los tipos más comúnmente ilustrados: las colecciones, las obras completas, y la edición suelta de piezas. Incluye Ribao una lista de las obras modernas que se editan ilustradas en el siglo XIX, de los siguientes autores: Ramón de la Cruz, Leandro Fernández de Moratín, Jovellanos, Larra, Luceño, Ramos Carrión, Urrecha, de la Vega, y Zorrilla. Junto a ellos, tres colecciones de autores varios: Colección selecta del teatro antiguo español (1854), Museo Dramático Ilustrado (1863-1864), y Teatro selecto antiguo y moderno (1866-1869). En la Colección selecta, solamente Moratín tuvo cabida de entre los modernos autores. Con los años, el nivel de alfabetización aumenta, y en la década de los sesenta, cuando aparece el Museo Dramático Ilustrado, la oferta de autores debe ser mayor. Su venta es por suscripción, cada entrega responde a una obra, y cada seis series se regala un juego de tapas e índice para encuadernar en tomos. El Museo se estructura en catorce series, cada serie incluye seis obras, y se mantiene un equilibrio entre adaptaciones, traducciones y originales. Las ilustraciones constituyen xilografías firmadas por Llopis, Planas, Brangulí y Gómez. En todas ellas, según Ribao, las ilustraciones sirven de reclamo para 
este tipo de lector. Destacable es la proliferación de las obras de Ramón de la Cruz, y el resurgimiento del sainete, que trae consigo toda una galería de retratos y escenas castizas de Llobera y Lizcano.

José María Ferri echa una mirada a la edición ilustrada de poemarios decimonónicos y otros textos, como El diablo mundo y El estudiante de Salamanca de Espronceda, ilustrada por Gaspar i Roig, o la segunda edición de los Cantos del trovador, impresa por Urrabieta. Estudia también obras de Campoamor y Núñez de Arce en la Biblioteca Arte y Letras, y una antología ilustrada de cantares populares y literarios. La sección dedicada a la prensa la abre Marta Palenque, atendiendo a la situación general de la ilustración en los periódicos, a la historia de la prensa ilustrada, desde la creación de El Artista en 1833. Se fija en el fenómeno del folletín, la prensa satírica, hasta llegar la modernidad ilustradora, que elabora en el capítulo siguiente al tratar la ilustración moderna en Blanco y Negro. Borja Rodríguez dedica unas páginas a la prensa romántica ilustrada, en publicaciones como El Artista, el Semanario Pintoresco Español, y El Laberinto.

Finalmente, en la sección designada a otras formas literarias, los diversos autores colaboradores se centran en aspectos ilustrados tan sugestivos como lecturas ilustradas de los nuevos lectores del siglo XIX, los libros de viajes y el caso de la España artística y monumental de Patricio de la Escosura, los almanaques y libros de lujo, estampas, aleluyas, cromos, postales, literatura infantil, y algunos casos aislados, como Recuerdos de la Guerra de África de Gaspar Núñez de Arce, la iconografía popular sobre el tema de don Juan Tenorio, o la Biblioteca Arte y Letras. Como broche a este volumen, una exhaustiva bibliografía que contempla de forma total la rica existencia de la literatura ilustrada española decimonónica.

\section{AUTORES}

\section{CARLOS MIGUEL-PUEYO}

Universidad de Valparaíso, Chile 